\title{
Business Process Model Variations in Islamic Boarding Schools Using Requirements Analysis Method
}

\author{
Fitri Nuriyanti*, Iffatul Izzah, Munajatul Azizah, Muhammad Ainul Yaqin \\ Informatics Engineering, State Islamic University of Maulana Malik Ibrahim Malang \\ J1. Gajayana No. 50, Dinoyo, district. Lowokwaru, Malang, East Java 65 144, Indonesia. Tel. (0341) 551354. \\ Email*: 16650032@student.uinmalang.ac.id
}

\begin{abstract}
The business process at a boarding school is a collection of all the detailed activities that have been arranged in such a way as to solve the existing problems so that the objectives set can be met. There are development standards that can be used as a reference to build architecture and business process models at a boarding school. Every business process has planned many ways to be able to obtain goals precisely. Therefore variations are formed in the business process models. Business process models of variations are a collection of business process models that have the same goals in different ways. Variations in the business process models are needed to achieve the right goals in a variety of ways according to existing resources and needs. From all reviews of the variations, it is necessary to have a cyclomatic complexity to find out how complex the business process models is and to maintain the simplicity of the business process models. This study uses the requirements analysis method, which is the intensive interaction stage between the system analyst and the system user community (end-user), where the system development team shows its expertise to get user feedback and confidence so that it gets good participation. The results of this study are a collection of variations of business process models that have a level of complexity not much different from one variation, with another on each standard applied.
\end{abstract}

Keywords: Business process models variations, cyclomatic complexity, requirements analysis

\section{INTRODUCTION}

The business process is a set of activities or work structured interrelated to complete a problem or produce a particular product or service (to achieve a particular purpose). The business processes in a boarding school is a collection of all the detailed activities which have been designed to solve existing problems so that the goals set can be met.

Model Business Process or Business Process Modeling is an activity that represents the activities of a company's business processes, so that business processes can be analyzed, improved and automated. In boarding school, business process model covers all existing activities ranging from design criteria for admission of students, creation of rules and discipline of students, employees, up to the parents, making a schedule of activities, to the distribution of the means that can be used. All the business processes to be modeled in detail the flow of the process. With the business process model that can each process can be analyzed and improved performance.

At a boarding school there are many business processes there are certainly many ways to fulfill the process. With dimodelkannya every business process can be easier to find other alternatives to achieve the desired process. This is called a variety of business process models. Variations in the business process is a process model that has a wide range of alternative outcomes leads to a set of process variations. (Jan vom Brocke, 2017). Variations in the business process model is a set of business process models that have the same goals in different ways.

Table 1. Related research

\begin{tabular}{|c|c|c|}
\hline Year & dentity & Information \\
\hline 2018 & $\begin{array}{l}\text { Ingrid EA Siahaan, Nana Yudi Setiawan, Aditya Rachmadi. } \\
\text { Evaluation of In Business Process Variation Blood Donor } \\
\text { Services (Case Study: UTD PMI Malang). Brawijaya } \\
\text { University. }\end{array}$ & $\begin{array}{l}\text { The journal Explains how to Evaluate variations of business } \\
\text { process models in UTD PMI Malang using value chain } \\
\text { analysis methods. In this journal, the research procedure is } \\
\text { explained from the beginning to the results. }\end{array}$ \\
\hline 2018 & $\begin{array}{l}\text { Annisa Arifa Sesyazhade, Nana Yudi Setiawan, Ismiarta } \\
\text { Aknuranda. Variation Analysis Business Process } \\
\text { Manufacturing With Applying Process Mining (Case Study: } \\
\text { PT Kimia Farma Tbk). Brawijaya University }\end{array}$ & $\begin{array}{l}\text { This journal Explains the } \\
\text { manufacturing business p } \\
\text { by simulating the SOP pre } \\
\text { YAWL event logs from th }\end{array}$ \\
\hline 2018 & $\begin{array}{l}\text { Sudarpi, Dimas Hariyanto. Business Process Modeling and } \\
\text { Evaluation of the Quality Evaluation Method Using } \\
\text { Framework (QEF) (Case Study: PT. Group Mitra } \\
\text { Indonesia). Brawijaya University }\end{array}$ & $\begin{array}{l}\text { This journal discusses the business process evaluation with } \\
\text { QEF by using BPMN so that the quality factor is found to be } \\
\text { inappropriate. Quality factor will help the company in } \\
\text { getting the root of the problem. }\end{array}$ \\
\hline
\end{tabular}


A business process can be modeled into activities that are more detailed. This modeling will be able to reach the right destination. Every business processes can be modeled into more than one business process model. Variations of this business process model is needed to achieve the right objectives in ways that vary according to the needs and resources available.

Requirement analysis is the stage of intensive interaction between the systems analyst community of users of the system (end-user), where the system development team showed his skills to get feedback and user confidence, so that it gets a good participation. Requirements analysis method consists of several stages of sampling, interviews, quesioner, and observation. The initial phase of the system requirement is to survey the user desires and explain the ideal information system.

In the development of business process models at a boarding school requirement analysis is needed to determine the needs and problems that exist in a boarding school. With the analysis of the necessary requirements development process models to meet the goals set.

\section{MATERIALS AND METHOD}

\section{Study area}

This research applied to the development of the business process model variations in a boarding school based on a predetermined standard. Business process models developed have the same purpose in a manner different fulfillment.

\section{Procedure}

The steps taken to develop a variety of business process models as follows:

\section{Identification of business process models}

Business process model is a representation of sequences of all functions related to a business activity (Prasetya, Arif Revelation: 2018). Business Process Model is an activity that represents the activities of a company's business processes, so that business processes can be analyzed, improved and automated. In the boarding school there are many models of business processes. Every business process models developed in accordance with the referenced standards development.

\section{Business model process variations}

Variations of business process models developed to meet various needs in various ways. Fulfillment process is also based on available resources. Produced so many ways to achieve goals (needs). The way to achieve this requirement is called business process model variations. At boarding school, each standard to model business processes. And each standard can have more than one business process model to achieve the same goal.

\section{Cyclomatic complexity}

Cyclomatic Complexity is a metric that is used to calculate the value of complexity. Cyclomatic complexity of a program can be created by using the following formula:

$$
\mathrm{V}(\mathrm{G})=\mathrm{E}-\mathrm{N}+2
$$

Information:

$$
\begin{array}{ll}
\text { V (G) } & \text { : Cyclomatic Complexity } \\
\mathrm{E} & \text { : Total edge } \\
\mathrm{N} & \text { : Number of nodes }
\end{array}
$$

\section{Requirement analysis}

Analysis needed to get problems done. Needs obtained from the interviews and surveys on the object of study, namely the boarding school. From the list of issues will be troubleshooting. The following is one requirement analysis results in a boarding school in the form of SOPs (Standard Operating Procedures).

Standards of Conduct, discipline, punishment, reward and restrictions

\section{- Customer reporting students}

1. Staff lodge security division received a report from the lodge staff who was in charge of students

2. The security division of students reported receiving data

3. Security division to record students who commit violations in the record book violation

\section{- Reporting prosecution}

1. Security Division received a report of troubled students

2. Division action against students who commit violations

3. Security division report to the person in charge of students if the students concerned have been given the action

4. Staff cottage responsible for the students to receive reports from the security division.

5. Staff cottage notes in notebook students

\section{- Meeting to decide punishment}

1. Security division outlines offenses committed students

2. Security division propose appropriate penalties for students who violate

3. Security division determine punishment that will be given to students who violate this.

4. Security division provides for punishment for students who violate this.

\section{Data analysis}

Business process models expressed in BPMN (Business Process Model Notation) to be calculated complexity. BPMN consists of several features, among others:

1. Event: Event is something that "happens" during the course of process or choreography. Affect the flow of the model and usually have a cause (trigger) or 
impact (result). Events depicted in the open circles to distinguish their functions. There are three types of events, based on the influence of process flow: The Beginning, Intermediate, and End.

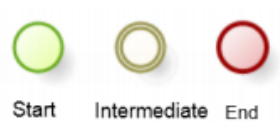

Figure 1. Event.

2. Activity: Activities is a general term for an activity that showed companies doing process. Types of Activities that are part of the process is a model Described rounded rectangle.

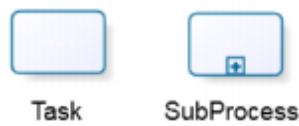

Figure 2. Activity.

3. Gateway: Gateway is used to control the difference and the convergence of the order flow in the process. Thus, it will determine branching, forking, merging, and joining lines

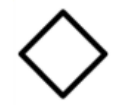

Figure 3. Gateway.

4. Sequence Flow A Sequence Flow is used to show the sequence of activities to be carried out in the process

Figure 4. Sequence Flow.

5. Message Flow is used to show the flow of messages between two actors who have been prepared to send and receive them. In BPMN, two separate Pools in the Diagram will represent the two participants Collaboration (eg partner entity or partner roles)

Figure 5. Message flow

6. Association Used to connect information and Artifacts with graphical BPMN elements. Explanatory text and other artifacts can be associated with the graphic element. All the arrowhead of the Association indicate the direction of flow (eg data)

Figure 6. Association.

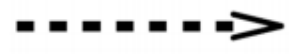

7. Pool is a graphical representation of actors/participants collaboration. It also acts as a "swimlane" and a graphical container for partitioning a set of activities dadi other Pools, usually in the context of B2B situations. Pool A may have a detailed internal, in the form of a process to be executed

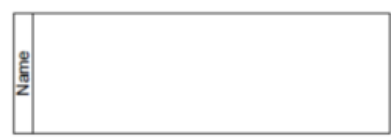

Figure 7. Pool.

8. Lane. Lane is a sub-partition in the process, sometimes in the Pool, will extend the entire process either vertically or horizontally. Paths are used to organize and categorize activities.

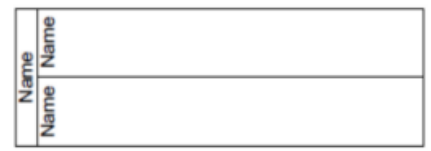

Figure 8. Lane.

9. Data Object: Data Object provides information on what activities need to be held or what they produce. Data Object can represent a single object or collection of objects. Data input and output data provide the same information for the process.

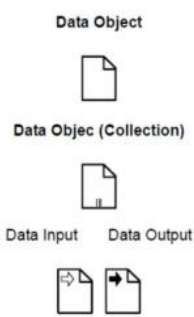

Figure 9. Data Object.

10. Group is a grouping of graphic elements that are in the same category. Type grouping does not affect the Sequence Flow in the Group. Category names appear on the diagram as a label group. Categories can be used for documentation or analysis purposes. Group is one of the ways in which the category of objects can be visually displayed in Chart

Figure 10. Group.

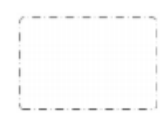

\section{RESULTS AND DISCUSSION}

\section{Variations Business Process Model}

Standards of Conduct, discipline, punishment, reward, and restrictions 


\subsection{Reporting violations of students}

- Variation 1

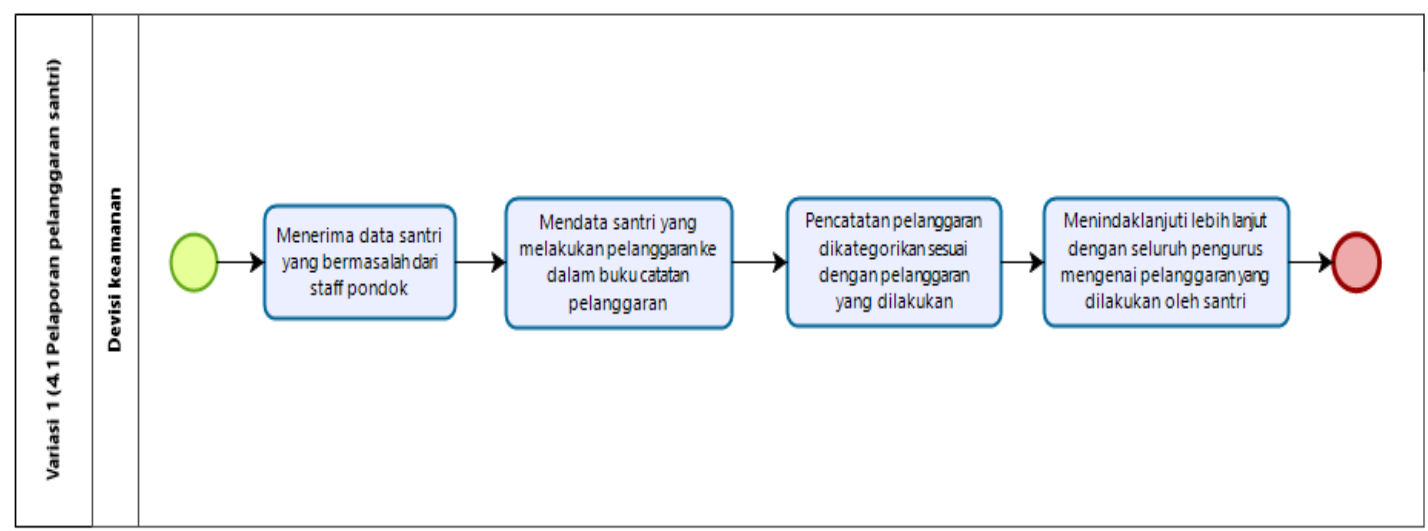

Figure 11. BPMN variation 1 students reporting violations.

\section{- Variation 2}

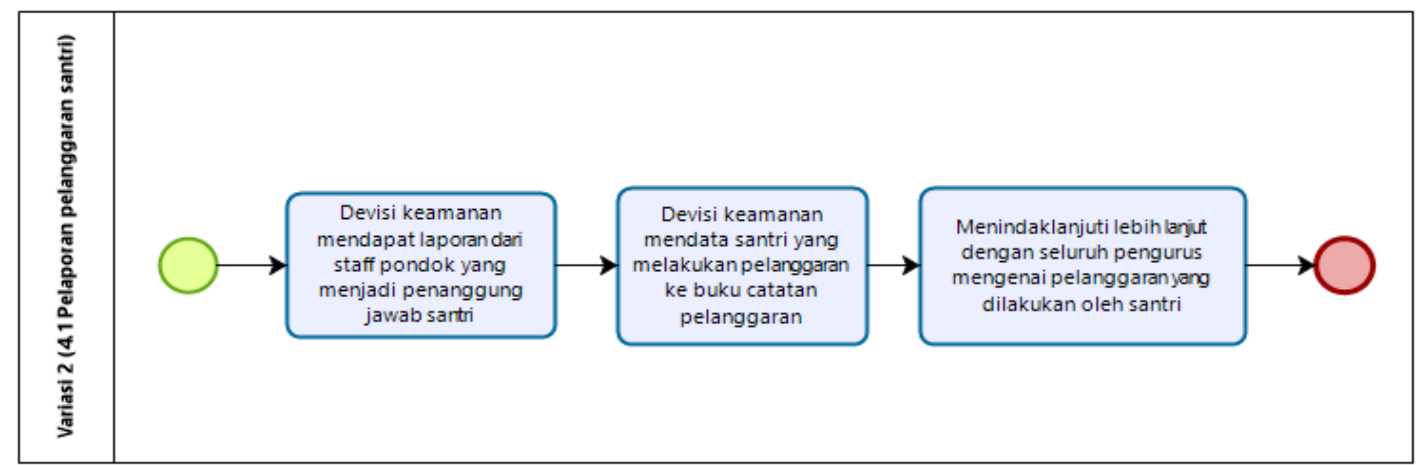

Figure 12. BPMN variation 2 students reporting violations.

\subsection{Report of action}

- Variation 1

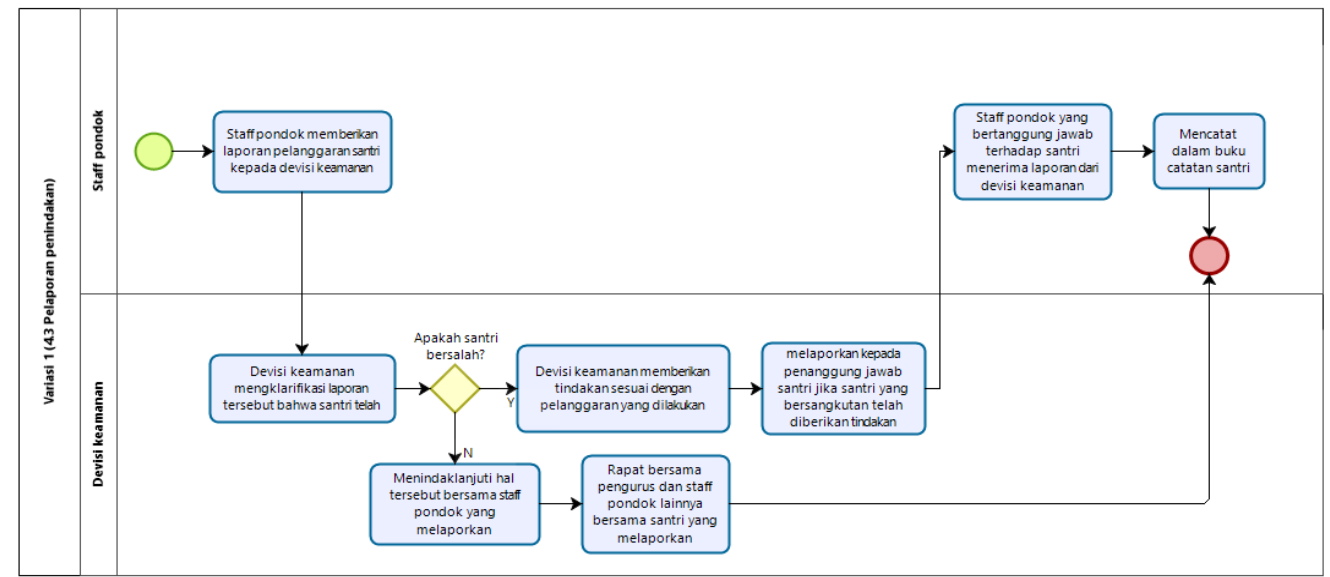

Figure 13. BPMN variation 1 action report. 
- Variation 2

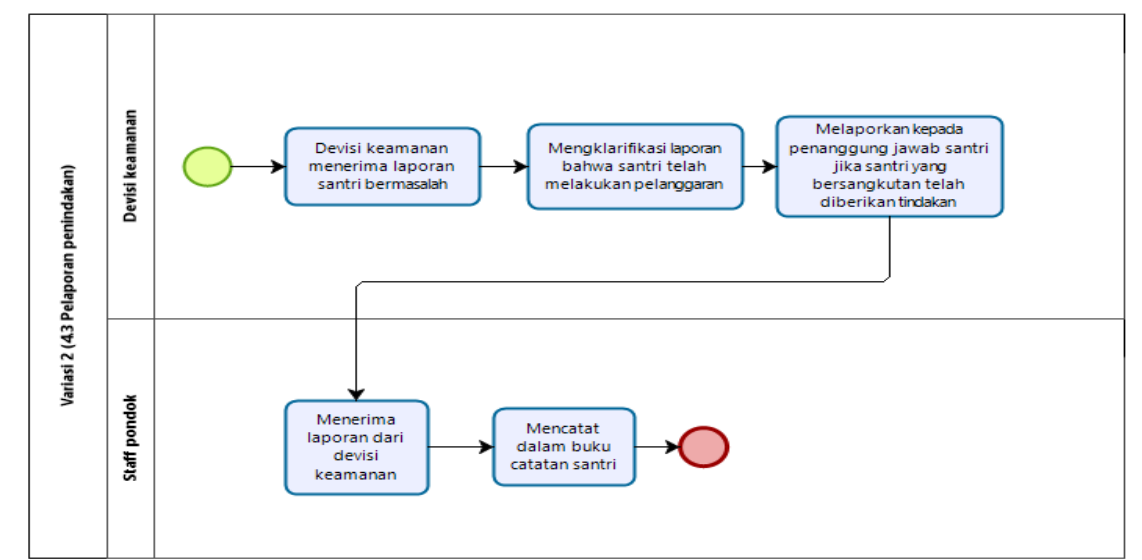

Figure 14. BPMN variation 2 reports the prosecution.

\subsection{Meetings to disconnect}

- Variation 1

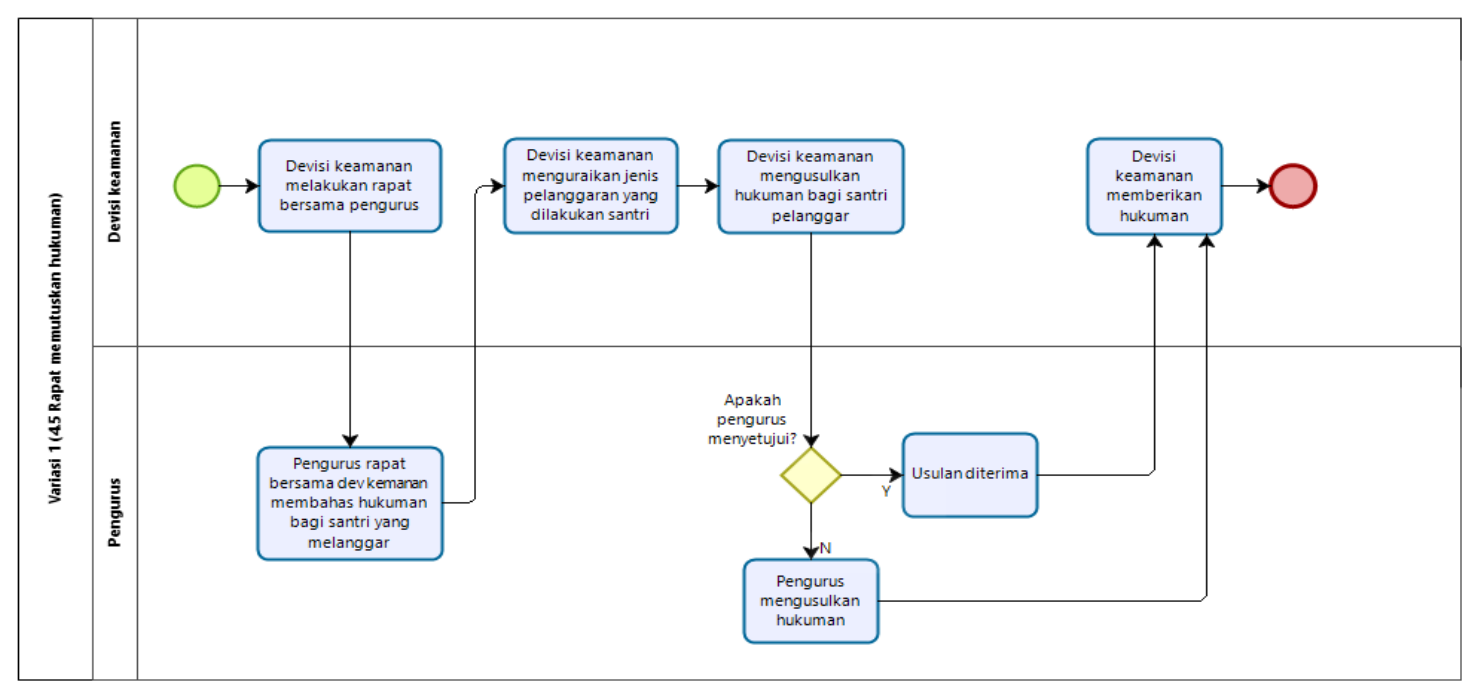

Figure 15. BPMN variation 1 meeting to disconnect.

\section{- Variation 2}

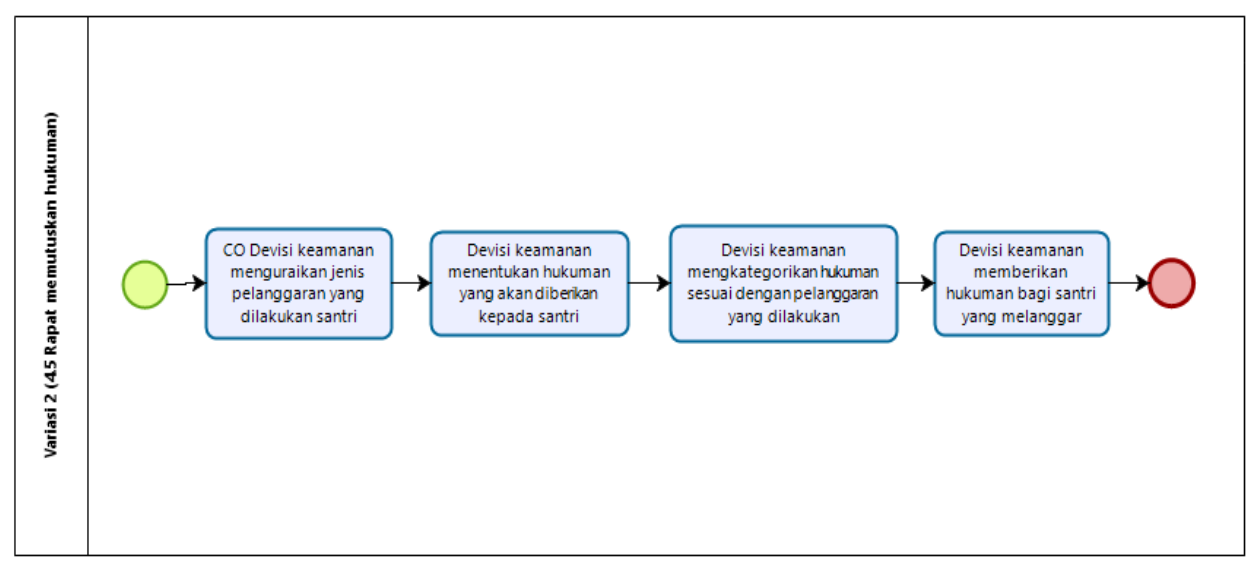

Figure 16. BPMN variation 2 meeting to disconnect.

Based on the images that have been displayed above it can be seen that to meet the standard, has a lot of ways. Differences in the way is called variation. Further variations obtained will be calculated complexity.

\section{Cyclomatic Complexity}

BPMN based on the variations above, the value of complexity by using cyclomatic complexity as follows: 
Table 2. Cyclomatic complexity calculation of standard 1.1.

\begin{tabular}{ccc}
\hline & \multicolumn{1}{c}{ 1.1 standard } \\
\hline & variation 1 & variation 2 \\
\hline $\mathrm{E}$ & 5 & 4 \\
$\mathrm{~N}$ & 6 & 5 \\
$\mathrm{~V}(\mathrm{G})$ & 1 & 1 \\
\hline
\end{tabular}

Table 3. Cyclomatic complexity calculation of standard 1.2.

\begin{tabular}{ccc}
\hline \multicolumn{3}{c}{ 1.2 standard } \\
\hline variation 1 & variation 2 \\
$\mathrm{N}$ & 11 & 6 \\
$\mathrm{~V}(\mathrm{G})$ & 11 & 7 \\
\hline
\end{tabular}

Table 4. Cyclomatic complexity calculation of standard 1.3.

\begin{tabular}{ccc}
\hline \multicolumn{3}{c}{ 1.3 standard } \\
\hline & variation 1 & variation 2 \\
\hline $\mathrm{E}$ & 10 & 5 \\
$\mathrm{~N}$ & 10 & 6 \\
$\mathrm{~V}(\mathrm{G})$ & 2 & 1 \\
\hline
\end{tabular}

From the development of the business process model variations based on the standards set by using the method of analysis requirement calculation results obtained show:

1. The complexity of each variation in each standard have differences that relatively little or almost the same. This proves that the variation developed can be applied to achieve the same needs in different ways.

2. Variations obtained can be used to multiply the repository, configuration, and production planning.

\section{CONCLUSIONS}

The results of this study are a collection of variations of business process models that have a level of complexity not much different from one variation with another on each standard applied.

\section{ACKNOWLEDGMENTS}

The authors are grateful to Mr. Muhammad Ainul Yaqin, M. Kom at the State Islamic University of Maulana Malik Ibrahim Malang for suggesting in writing this manuscript. This study was supported in part by the State Islamic University of Maulana Malik Ibrahim Malang.

\section{REFERENCES}

Annisa AS, Nanang YS, Ismiarta A. 2018. Analisis Variasi Proses Bisnis Manufaktur Dengan Menerapkan Process Mining (Studi Kasus: PT Kimia Farma, Tbk). Universitas Brawijaya 2: 12 .

Arif WP, Muhammad AY, Syahiduz Z. 2018. Common Process Extraction Pada Scalable Model Proses Bisnis. Universitas Islam Negeri Maulana Malik Ibrahim Malang.

Inggrid EA Siahaan, Nanang YS, Aditya R. 2018. Evaluasi Pada Variasi Proses Bisnis Layanan Donor Darah (Studi Kasus: UTD PMI Kota Malang). Universitas Brawijaya 2: 12.

Raden ARF, Irman H. 2018. Instrumentasi Kode Program Secara Otomatis untuk Path Testing Automatic Source Code Instrumentation for Path Testing. Institut Pertanian Bogor. 5: 41.

Sudarpi, Dimas H. 2018. Pemodelan dan Evaluasi Proses Bisnis Menggunakan Metode Quality Evaluation Framework (QEF) (Studi Kasus: PT Group Mitra Indonesia). Universitas Brawijaya 2: 9.

Yudhanto Y. 2016. Pengantar BPMN Business Process Modeling Notation. Ilmu Komputer.Com 